\title{
Microfinance and Climate Change Adaptation
}

\author{
Anne Hammill, Richard Matthew and Elissa McCarter
}

\begin{abstract}
1 Introduction
In 2006, the Nobel Peace Prize was awarded to Mohammed Yunus and the Grameen Bank for their roles in developing microfinance as an 'ever more important instrument in the fight against poverty' (Norwegian Nobel Committee 2006). The following year, the award was given to $\mathrm{Al}$ Gore and the Intergovernmental Panel on Climate Change (IPCC), for their roles in educating the world about the unprecedented global challenge of climate change. In making these unusual and even controversial awards, the Nobel Committee recognised the remarkable fact that, in the space of just three decades, microfinance and climate change science have generated broad social movements grounded in the belief that these processes have the capacity to radically transform life around the world.
\end{abstract}

Ironically, while in their most optimistic expressions, the proponents of microfinance imagine cutting global poverty in half within a few years, scientists have identified the same population of desperately poor as among the first people who will confront the negative impacts of climate change. Specifically, the IPCC has identified developing countries as more vulnerable to climate change damages and argues that 'this condition is most extreme among the poorest people' (IPCC 2001: 227). Development assistance agencies have warned that climate change may stall or reverse development efforts, making it more difficult to achieve the Millennium Development Goals (MDGs) (ADB et al. 2003). If climate change is indeed a threat to which the poor are acutely vulnerable and if microfinance is in fact a tool that can reduce the vulnerability of the poor, then the possibility of linking this tool to climate change adaptation is of considerable importance.

Some caution is appropriate however, since in many ways microfinance is 'an immature and unproven field
... anyone can say almost anything, and with the public relations surrounding the field, much of it goes unquestioned' (Dichter 2007: 4-5). The flurry of activity and interest surrounding microfinance has in some ways obscured the fact that the microfinance industry is still fragmented, composed of a broad range of operators offering different products and services at different scales, often with insufficient data to quantify or prove results (Hulme 2007; Karnani 2007). The industry itself is undergoing significant transformation, as more and more nongovernmental organisation (NGO) microfinance institutions become regulated financial institutions, and as more commercially oriented investors begin to finance their growth, raising concerns about mission drift (Frank et al. 2008). Industry proponents appear to be taking steps to manage expectations and improve transparency, noting that microfinance was not intended to serve the very poorest of the poor, but the 'economically active poor' and represents only one (sometimes minor) strategy for poverty reduction.

While appreciating the various concerns raised about microfinance, our review of what is an increasingly sophisticated literature suggests that microfinance deserves careful consideration by the climate change adaptation community. We believe that the potential for a constructive linkage is there - in some cases much has already been realised - and should not be ignored. Hence the purpose of this article is to identify possible links between microfinance services and climate adaptation and to highlight the opportunities and the risks of these links for vulnerability reduction among the world's poorest populations.

\section{The challenge of climate change and the need to adapt}

Climate change has moved beyond being an environmental challenge to one that threatens poverty reduction and development around the 
world. The scientific community has confirmed that the world is now locked into a pattern of change and the opportunity for preventing any warming has now passed (IPCC 2007). Societies must therefore respond by both minimising further warming (by reducing the concentration of greenhouse gases in the atmosphere) and finding ways to adapt to the impacts that warming will bring, such as shifting precipitation regimes, more frequent and severe extreme weather events, and sea-level rise.

Adaptation is a process of adjustment to new or modified circumstances. Within the context of climate change, adaptation is understood as the actions people take in response to, or in anticipation of changing climate conditions in order to reduce adverse impacts or take advantage of any opportunities that may arise (Tompkins and Adger 2003). The need for, type and scale of adaptation depends on the kind of change taking place, as well as the vulnerability of people and natural systems to this change. Vulnerability in this sense is a system's exposure to, as well as ability to cope with and recover from, disruptive shocks and trends (IPCC 2001; IISD et al. 2003a).

Reducing peoples' vulnerability to climate change is closely linked to the poverty reduction agenda, since poverty is both a condition and determinant of vulnerability. Many of the world's poor are already vulnerable to climate risk due to factors such as settlement on marginal lands, high dependence on climate-sensitive livelihoods, and limited access to or availability of resources to respond to shocks and stresses (ADB et al. 2003). Climate change will amplify, modify or introduce new types of threats, which may affect natural and human systems independently or in combination with other determinants to alter productivity, diversity and functioning of ecosystems and livelihoods (IISD et al. 2003b). If people do not have the resources to deal with today's stresses, then they are unlikely to be able to deal with the additional stresses associated with climate change, a condition known as the 'adaptation deficit' (Burton 2004).

Adaptation to climate change must start with reducing this deficit. To this end, many strategies currently used for development and poverty reduction have an important role to play. Indeed, a recent survey of adaptation efforts found that the majority of cases used 'methods and approaches that come straight from the development toolbox' (McGray et al. 2007). But leveraging development tools for adaptation may involve more than just implementing what seems to already work for vulnerability and poverty reduction and require us to think about how decisions taken today could have implications for future vulnerability. Climate change has in effect introduced greater uncertainty into development decision-making, extended the decision-making timeframe, and further emphasised the potential trade-offs between short-term development gains and longer-term socioeconomic transformation, particularly among the world's poor. Today's development toolbox must therefore be understood in terms of these new decision-making conditions.

\section{The promise of microfinance}

Microfinance services (MFS) have been part of the development toolbox for some 30 years. Microfinance is the delivery of loans, savings, insurance and other financial services to the poor so they can engage in productive activities, helping them build assets, stabilise consumption and protect themselves against risk. MFS builds on two traditional forms of financial mediation in poor communities - moneylenders and local savings groups - by formalising, expanding, and in many cases modernising, the transactions and services offered to them (Harper 1998). Microfinance institutions aim to fill the market gaps left open by traditional banks and state-run development programmes, which have been unwilling or unable to effectively provide financing for the poor.

Its most common form, microcredit, operates on the principle that the poor cannot get loans from traditional banks because they do not have the collateral to secure them; MFIs disburse loans as small as $\$ 50$, the administration of which is made possible by charging relatively high interest rates and requiring frequent (e.g. weekly) loan repayments. Typically, borrowers are organised into groups that share responsibility for these payments, at least until a borrower is able to acquire loans on an individual basis. If a member defaults on his or her payment, then the others are obligated to repay it. In some cases, MFls serve as the intermediary between individuals or groups and banks, a delivery system known as the partner-agent model, which has grown rapidly in India in recent years. 
The world's reported 3,300 MFls come in many shapes and sizes (Daley-Harris 2007). The largest and most formal institutions are generally governmentowned or private development banks, which are subject to general and commercial laws as well as banking regulations and supervision. Non-bank financial institutions such as credit unions, savings and loan cooperatives, and non-governmental organisations (usually under specified microfinance legislation) make up the majority of MFIs. These organisations are subject to local laws, but many are not held to formal banking regulations as they are not permitted to collect deposits. Some microfinance organisations offer non-financial services such as education, training and healthcare, in order to reinforce economic and social development capacities among their clientele.

The promise of microfinance is the ability of some of the largest institutions to reach a base clientele of literally hundreds of thousands of poor families, through distribution channels that serve concentrated slums in urban areas as well as remote rural communities. Technological advancements in the industry such as branchless banking, cell phone transactions, and other innovations suggest that growing smaller MFls to scale, although relatively few in number, is possible. Product offerings that recognise the value in savings and microinsurance services are also growing (Helms 2006).

However, several challenges remain for the microfinance industry to achieve greater scale and outreach, and in order to see its real potential for helping to address vulnerability. First, it is still a largely credit-driven service, not appropriate for the poorest individuals for whom indebtedness is not the answer, and thus it should not try to replace government or other interventions to create safety nets needed for this segment of the population. Second, there remains a delicate balance for MFIs to achieve deeper outreach to poorer individuals while also achieving sustainability and a strong financial position to attract further financing from investors. Third, while financing remains a constraint there is also a need to improve governance, management, transparency, and build the human capital necessary to manage growth and protect against the institutional risks inherent in the financial services business that could ultimately be damaging to borrowers (e.g. fraud prevention, operating inefficiencies that lead to persistently high interest rates and lack of consumer education or transparency about products as systems become more sophisticated).

Finally, financial services alone cannot address the more complex structural problems of poverty and vulnerability. For this reason, and most applicable to the case for using microfinance as a tool in climate change adaptation, it is important to look at microfinance coupled with education, or coordinated with other country growth strategies or market interventions, that promote a longer-term view to sustainable economic development. There are positive examples of programmes that link microfinance and HIV/AIDS awareness, microfinance and vocational skills training, and although just beginning, microfinance and environmental protection (Barnes 2005; MkNelly and Dunford 1998). Lessons from these programmes can be further explored and applied to the case for using microfinance as a tool for adaptation to climate change.

\section{How can MFS contribute to climate change adaptation?}

MFS has the potential to help the world's poor and most vulnerable populations adapt to climate change by providing poor individuals and households with a means of accumulating and managing the assets and capabilities needed to become less susceptible to shocks and stresses and/or cope with their impacts. The logic here is simple - the more assets and capabilities people have, the less vulnerable they are (Swift 1989; Moser 1998; Ellis 2000). Of course, some assets and capabilities will be better suited to promoting climate change adaptation than others, and the optimal mix needs to be determined at the community or household level.

The types and mix of assets we are talking about can be understood in terms of a livelihood's framework, where people mobilise and manage different types of assets - financial, physical, human, social and natural - to undertake livelihood strategies in the pursuit of desired livelihood outcomes (Scoones 1998; DFID 1999). Microfinance services can enhance the livelihood asset base through direct income effects, indirect income effects (from education and training), and non-pecuniary effects (i.e. stronger social networks and increased confidence) (Galab et al. 2006; de Aghion and Morduch, cited in Swain and Floro 2007). Looking more closely at the main types of microfinance services described in the 
Table 1 Microfinance services and livelihood assets: examples

\begin{tabular}{|c|c|c|}
\hline & Direct contribution of MFS & Less direct contribution of MFS \\
\hline Financial & $\begin{array}{l}\text { - Cash/capital for investing livelihood activities } \\
\text { - Savings (depending on credit scheme) } \\
\text { - Increase in household assets } \\
\text { - Diversification of assets }\end{array}$ & $\begin{array}{l}\text { - More regular inflows of money } \\
\text { - Financial safety nets } \\
\text { - Credit standing for future loans } \\
\text { - Improved skills/capacities in financial } \\
\text { management }\end{array}$ \\
\hline Social & $\begin{array}{l}\text { - Establishment or strengthening of social } \\
\text { networks } \\
\text { - Establishment or strengthening of } \\
\text { formalised groups }\end{array}$ & $\begin{array}{l}\text { - Reinforced relationships of trust, reciprocity } \\
\text { and exchange (i.e. through loan groups) } \\
\text { - Informal safety nets } \\
\text { - Increased access to civic or political bodies } \\
\text { - Increased social prestige and value } \\
\text { - Increased sense of wellbeing } \\
\text { - Women's empowerment, increased } \\
\text { self-confidence }\end{array}$ \\
\hline Natural & $\begin{array}{l}\text { - Practice of sustainable soil and water } \\
\text { management techniques as a loan condition } \\
\text { (e.g. more favourable interest rates) }\end{array}$ & $\begin{array}{l}\text { - Capital for investing in sustainable natural } \\
\text { resource management (SNRM) practices; } \\
\text { renewable energy } \\
\text { - Reduced pressure on natural resource base } \\
\text { (as activities are improved or diversified) } \\
\text { - Enhanced skills and institutions for SNRM } \\
\text { - Political empowerment to secure resource } \\
\text { rights, land tenure }\end{array}$ \\
\hline Human & $\begin{array}{l}\text { - Loans for education, healthcare } \\
\text { - Skills training, education (depending on } \\
\text { credit scheme) }\end{array}$ & $\begin{array}{l}\text { - Increased literacy, knowledge base } \\
\text { - Better health } \\
\text { - Improved ability to labour and employability - } \\
\text { expanding labour force }\end{array}$ \\
\hline Physical & $\begin{array}{l}\text { - Loans for equipment, infrastructure } \\
\text { - Housing, sanitation improvements (as part } \\
\text { of credit package) }\end{array}$ & $\begin{array}{l}\text { - Better health and living environment } \\
\text { - Better infrastructure or equipment (able to } \\
\text { invest in better quality and more, result of less } \\
\text { intense use) }\end{array}$ \\
\hline
\end{tabular}

previous section, their links to asset accumulation can be described as follows:

- Microcredit, which focuses on lending funds to poor people so they are able to exploit their capacities for income production (job creation, enterprise growth, increased production), is about asset building and diversification. Returns are consumed, saved, reinvested or some combination of all three. Loans are also offered for nonproductive purposes that may also contribute to reducing vulnerability, such as emergency loans, education loans, and home improvement loans.

- Microinsurance (see Pierro and Desai, this IDS Bulletin) provides poor people with protection against specific perils (injury, death, natural hazards) in exchange for regular premium payments (Churchill 2006). Thus, it is about protecting assets and giving people the freedom to pursue profit without fear, which would ideally lead to increased income production (Morduch 2006).

- Microsavings are small balance deposits for the safe storage of money, allowing people to access lump sums to meet both predictable and unpredictable expenses. They can be used as insurance and/or for investment, yielding the same results on asset bases described above.

In Table 1 we elaborate on some of these relationships, offering examples of how microfinance 


\section{Box 1 Microfinance and disaster risk reduction (from Pantoja 2002).}

A wide range of microfinance services are available to help poor individuals and households undertake ex ante risk management and ex post coping measures. For example, the Self Employed Women's Association (SEWA) in India offers housing loans to repair or replace roofs, reinforce walls, or rebuild in less hazard-prone areas, which can be key for reducing vulnerability to extreme events such as floods, droughts and storms. Bangladesh Unemployed Rehabilitation Organisation (BURO), a nonprofit MFI, offers contractual term savings which require clients to make regular savings deposits for a fixed period of time in exchange for the guarantee that they will be able to withdraw a large proportion (e.g. 75 per cent) of the accumulated balance without penalty during a disaster. This type of arrangement can help people to self-insure and pursue riskier and potentially more profitable livelihood activities. In some cases, this may involve assuming more risk (i.e. loans or debt) to pursue enterprise or income-generating activities in trade (e.g. in foodstuffs, clothes), production (e.g. tailoring, baking) or services (e.g. beauty salons, funeral parlors), which - if profitable - would build a household's asset base.

The likely success and efficacy of these microfinance services can be strengthened through the provision of 'life skills' training in areas such as literacy, health and hygiene (e.g. disease prevention, nutrition during pregnancy), financial management (e.g. bookkeeping, investment decision-making), and specific technical/entrepreneurial skills (e.g. livestock rearing, food storage, fish processing). After all, a literate, healthy client base that is able to manage financial assets and identify and pursue new livelihood opportunities poses fewer risks to MFls and helps households reduce their own exposure to risk, including those associated with disasters.

services can enhance livelihood assets. The examples are neither universal nor comprehensive, but simply indicative of the different ways in which MFS can contribute to sustainable livelihoods.

Table 1 highlights the economic and non-economic assets that can be acquired or strengthened through MFS. In this regard, asset accumulation should also be understood in terms of the capacity to manage them, i.e. to transform them into income, food or other resources for individual or household wellbeing (Moser 1998). The empowerment of women offers a useful example. In her study of women's participation in microcredit programmes in Bangladesh, Mahmud (2003) concludes that while there was a limited direct effect on increasing women's access to structurally determined 'choice-enhancing' resources (i.e. those assets traditionally under male control, such as land), there was a significant effect on their exercise of intra-household agency. Women became more actively involved in decisions regarding the use of loans and resulting incomes, which were important determinants of personal and household welfare.

Thus, whether it is increased social agency and political participation, stabilised hillsides, enterprise skills or more agricultural equipment, taken together the accumulated livelihood assets leveraged by MFS can help individuals and households take measures to reduce vulnerability. These can be broadly divided into ex ante risk management and ex post coping (Ellis 2000). The former implies forward planning to minimise and spread risk (e.g. accumulate assets, diversify income sources, reinforce reciprocity agreements), while the latter refers to maintaining consumption during and after a crisis (e.g. search for new credit/income, sell assets, reduce consumption). Credit, insurance and savings therefore help households protect and build up enough assets so that the impact of a shock or stress is not as immediate or damaging, i.e. they are able to minimise or entirely avoid depleting their asset base, or have a larger asset base from which to draw in order to deal with variances in income and consumption (Box 1).

The value MFS holds for climate change adaptation is in its outreach to vulnerable populations through a combination of direct and indirect financial support, and through the long-term nature of its services that help families build assets and coping mechanisms over time, especially through savings - and increasingly, microinsurance - products and sharing of knowledge and information to influence behaviours. 


\section{Figure 1 Microfinance clients}

Sestitute Extreme poor Moderate poor

\section{The limitations and risks associated with MFS} for adaptation

Despite the potential and realised contribution of MFS to vulnerability reduction among the world's poor, these services present certain limitations and risks that need to be carefully considered from the perspective of adaptation to climate change. We identify four issues that should provoke pause for thought.

\subsection{Outreach}

Microfinance services typically do not reach the poorest of the poor, who are often the most difficult to reach in a systematic fashion and who have urgent and immediate basic needs. They are over-represented by socially excluded groups such as sex workers, the disabled and elderly, street children and refugees. Trapped in an economy of survival, they have the farthest distance to travel for their poverty to be reduced and for the possibility of development to become real to them. Thus, MFS works best to support the economically active poor, or those hovering just above the poverty line to help them stay above it (Figure 1).

Moreover, microfinance in Africa - which is identified as the continent most vulnerable to the impacts of climate change (IPCC 2007) - is underdeveloped and possesses higher operating costs than other regions in the world (Helms 2006). If the poorest and the most vulnerable are indeed an adaptation priority, then MFS may not be the most effective tool for responding to this priority.

\subsection{Directionality}

A related issue has to do with the extent to which microcredit in particular may promote and reinforce coping practices, smoothing consumption the household level but not increasing income through productivity gains. In other words, does it simply keep people at the same level of poverty, preventing them from falling further below the poverty line, or does it actually provide a pathway out of poverty? While helping people cope with poverty has considerable moral appeal, from an adaptation perspective it raises the contentious question of whether it ultimately makes a larger number of people vulnerable to disasters than would otherwise be the case. Whether it is good or bad to introduce resources into a community that serves mainly to help people cope with poverty is a complex question. Here we can only speculate that whenever MFS is essentially a coping mechanism, it is not likely to be a pathway towards adaptation and could even increase vulnerability (see below). On the other hand, the classic success story of small loans that allow families to get on their feet, accumulate savings, and develop into other, more productive activities (especially when coupled with education or vocational skills training) suggests that MFS can create the platform for the first steps towards development, in which case vulnerability might decrease over time. The key question here is whether MFS sustains a survival economy or gradually builds pathways out of it.

\subsection{Vulnerability}

Related to the last point, there are other ways in which MFS have the potential to increase rather than reduce vulnerability at the household and community levels. These include increasing the debt burden, i.e. risk, of individuals and families, which may be especially disempowering for women if they are compelled to assume all the liability but do not 
Figure 2 MFS product purpose and client preferences

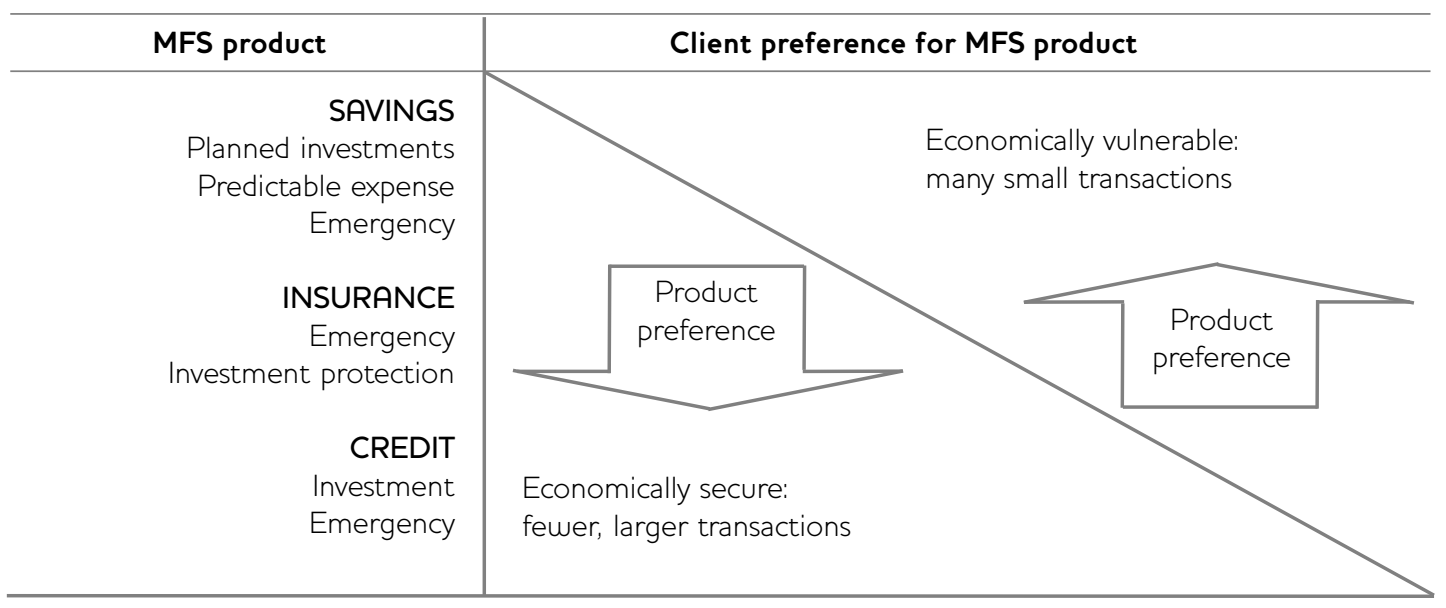

Source Adapted from Allen (2007).

have the agency to make livelihood decisions. Even if loans are used for risk reduction in the short term through measures such as housing repairs, livestock vaccination, or acquisition of land title deeds, servicing these loans or debts may increase longerterm risks if they do not translate into stable or increased income levels (Pantoja 2002). The cycle of debt may encourage individuals and households to reduce vital consumption (e.g. eat less), assume more risk by, for example taking out more loans, and/or exchange, sell (deplete) livelihood assets in order to repay loans (and save face among members of a loan group). Another area of concern has to do with the environmental impacts of MFS and the fear that it could replicate the degradation associated with other forms of capital operating at various scales. Empirical research on each of these issues is relatively thin and it is not possible to draw firm conclusions here. Nonetheless, several compelling case studies of specific MFIs and specific recipient communities have concluded that the net impact of various gains and losses associated with MFS is to empower women and reduce vulnerability (Amin et al. 2003; Anderson et al. 2002; Elahi and Danopoulos 2004; Khandker 2005; Mahmud 2003).

\subsection{Privatisation}

A final area of concern focuses on the extent to which MFIs (and many other NGOs) emerge to fill the gaps left by new or corrupt states, but then begin to relieve these states of the need to provide the basic services they ought to be providing. For some analysts, states mature and grow by struggling to meet social challenges. As they fight to build critical infrastructure, reduce illiteracy and create jobs, they gain both legitimacy and experience. When these things are done by third parties, the state misses opportunities to develop. It remains weak and ineffective, illegitimate in the eyes of many and susceptible to corruption. While in most cases the dollar value represented by microfinance operators remains too small a force to really see an impact, the recent enthusiasm to finance the poor rather than establish appropriate safety nets and good government policies to address the issues creating poverty is a real concern.

\section{Conclusions: making MFS work for adaptation}

This article is a first step towards unpacking the links between microfinance, vulnerability reduction and adaptation to climate change. In concluding, we offer a few observations and recommendations for pursuing these linkages.

1 Remember the most promising linkage: The most powerful case for MFS with regard to climate change adaptation is its ability to help families build and diversify assets, so that they have more than one means of livelihood; more than one skill set to avoid dependency. In high risk areas (such as flood- or hurricane-prone regions), microinsurance schemes or savings may be the 
only (imperfect) MFS option for dealing with risks. MFls can serve as distribution channels for donors to reach families in these areas when done in such a way that does not mix development aid (handouts) with loans (the lender/borrower financial contracts).

2 Manage expectations: The MFS industry has constructed a powerful image of itself as reaching the poorest of the poor with development tools. While some MFls do serve this population, they are probably providing more support for coping than for development. Much MFI activity focuses on the next rung up the economic ladder where they do indeed build safety nets for those families who are at or just above the poverty line, to prevent them from falling below it again.

3 Match MFS with client needs: MFS can be most effectively harnessed for vulnerability reduction when reflective of peoples' level of poverty and livelihood characteristics. As Allen (2007) notes, the poor tend to be 'much more interested in services that protect productive assets and reduce risks to their livelihoods' and as such, savingsrelated services may be the most accessible and appropriate for the poorest individuals and households. Figure 2 represents the relationship between different MFS clients and MFS product categories (i.e. savings, insurance and credit). While all MFS products are useful for emergencies and planned investments, the very poor tend to prefer low-risk savings-based

\section{References}

ADB (African Development Bank); Asian Development Bank; Department for International Development: United Kingdom; Directorate-General for International Cooperation: the Netherlands; Directorate General for Development: European Commission; Federal Ministry for Economic Cooperation and Development: Germany; Organisation for Economic Co-operation and Development; United Nations Development Programme; United Nations Environment Programme; World Bank (2003) Poverty and Climate Change: Reducing the Vulnerability of the Poor Through Adaptation, www.oecd.org/dataoecd/60/ 27/2502972.htm (accessed 22 June 2008)

Allen, H. (2007) 'Finance Begins with Savings, not Loans', in T. Dichter and M. Harper (eds), What's services that may require many small transactions, making it hard for MFls to provide a profitable service (Allen 2007).

4 Green microfinance: Many of the world's poor are directly dependent on ecosystem services for their survival and wellbeing. What is more, environmentally degraded systems can enhance disaster risk, leaving people more exposed to hazards such as landslides, floods and storm surges. Yet in the push to secure quick returns on loans, individuals and households may undertake income-generating or enterprise activities that deplete and degrade the natural asset base. 'Green microfinance', through service conditions that incentivise sustainable resource stewardship, may reinforce longer-term vulnerability reduction gains. While the need for 'green microfinance' is recognised, much more needs to be done and, importantly, not at the expense of positive social impacts. Balancing out quick gains and short-term loan repayment schedules with longer-term sustainable management practices will continue to challenge the industry and the people it serves, but promising experiences are starting to emerge. In Nicaragua, for example, a local MFI offered more loans at lower interest rates to farmers who agreed to undertake sustainable soil and water management practices (personal communication 2007). In short, the realisation of a 'triple bottom line' (economic, social and environmental returns) in MFS would be a valuable contribution to vulnerability reduction and climate adaptation in developing countries.

Wrong with Microfinance?, Warwickshire: Practical Action Publishing

Amin, S.; Rai, A.S. and Topa, G. (2003) 'Does Microcredit Reach the Poor and Vulnerable? Evidence from Northern Bangladesh', Journal of Development Economics 70.1: 59-82

Anderson, C.L.; Locker, L. and Nugent, R. (2002) 'Microcredit, Social Capital, and Common Pool Resources', World Development 30.1: 95-105

Barnes, C. (2005) 'Microcredit and Households Coping with HIV/AIDS: A Case Study from Zimbabwe', Journal of Microfinance 7.1: 55-77

Burton, I. (2004) 'Climate Change and the Adaptation Deficit', in Adam French (ed.), Climate Change: Building the Adaptive Capacity, paper from an International Conference on Adaptation Science, Management, and Policy Options, Lijiang, Yunnan, 
China, 17-19 May, Toronto: Meteorological Service of Canada, Environment Canada

Churchill, C. (2006) Protecting the Poor: A

Microinsurance Compendium, Geneva: International Labour Organisation

Cohen, M. (2003) The Impact of Microfinance, CGAP Donor Brief 13, www.cgap.org/gm/document-19.2407/DonorBrief_13.pdf (accessed 9 July 2008)

Daley-Harris, S. (2007) State of the Microcredit Summit Campaign Report 2007, www.microcreditsummit.org/ pubs/reports/socr/2007.html (accessed 20 June 2008)

DFID (1999) Sustainable Livelihoods Guidance Sheets,

London: Department for International

Development

Dichter, T. (2007) 'Introduction', in T. Dichter and M. Harper (eds), What's Wrong with Microfinance?, Warwickshire: Practical Action Publishing: 1-6

Elahi, K.Q. and Danopoulos, C.P. (2004) 'Microfinance and Third World Development: A Critical Analysis', Journal of Political and Military Sociology 32.1: 61-77

Ellis, F. (2000) 'The Determinants of Rural Livelihood Diversification in Developing Countries', Journal of Agricultural Economics 51.2: 289-302

Frank, C. (with contributions from Lynch, E. and Schneider-Moretto, L.) (2008) Stemming the Tide of Mission Drift: Microfinance Transformations and the Double Bottom Line, Women's World Banking, www.microfinancegateway.org/files/ 48712_file_pub_lang_WWBworkingpaper.pdf (accessed 19 May 2008)

Galab, S.; Fenn, B.; Jones, N.; Raju, D.S.; Wilson, I. and Reddy, M.G. (2006) Livelihood Diversification in Rural Andhra Pradesh: Household Asset Portfolios and Implications for Poverty Reduction, Working Paper 34, Oxford: Young Lives

Harper, M. (1998) Profit for the Poor: Cases in Microfinance, London: ITDG Publishing

Helms, B. (2006) Access for All: Building Inclusive Financial Systems, Washington DC: World Bank

Hulme, D. (2007) 'Is Microdebt Good for Poor People? A Note on the Dark Side of Microfinance', in T. Dichter and M. Harper (eds), What's Wrong with Microfinance?, Warwickshire: Practical Action Publishing: 19-22

IISD, IUCN - The World Conservation Union and Stockholm Environment Institute - Boston Centre (2003a) Livelihoods and Climate Change: Combining Disaster Risk Reduction, Natural Resource Management and Climate Change Adaptation in a New Approach to the Reduction of Vulnerability and
Poverty, Manitoba: International Institute for Sustainable Development, www.iisd.org/pdf/ 2003/natres_livelihoods_cc.pdf (accessed 10 July 2008)

IISD, IUCN - The World Conservation Union and Stockholm Environment Institute - Boston Centre (2003b) Increasing Community Resilience to ClimateRelated Disasters through Sustainable Livelihoods: A Conceptual Framework for Climate Change Adaptation, Livelihoods and Climate Change Information Paper 1, Manitoba: International Institute for Sustainable Development

IPCC (2007) Contribution of Working Group I to the Fourth Assessment Report of the Intergovernmental Panel on Climate Change: The Physical Science Basis Summary for Policymakers, www.ipcc.ch/ipccreports/ ar4-wg1.htm (accessed 8 July 2008)

IPCC (2001) Climate Change 2001: Synthesis Report, A Contribution of Working Groups 1, II, and III to the Third Assessment Report of the Intergovernmental Panel on Climate Change, Cambridge: Cambridge University Press

Karnani, A. (2007) 'Microfinance Misses its Mark', Stanford Social Innovation Review, Summer: 34-40

Khandker, S.R. (2005) 'Microfinance and Poverty: Evidence Using Panel Data from Bangladesh', World Bank Economic Review 19.2: 263-86

Mahmud, S. (2003) 'Actually how Empowering is Microcredit?', Development and Change 34.4: 577-605

McGray, H.; Hammill, A. and Bradley, R. (with Schipper, E. Lisa and Parry, J.) (2007) Weathering the Storm: Options for Framing Adaptation and Development, Washington DC: World Resources Institute

MkNelly, B. and Dunford, C. (1998) Impact of Credit with Education on Mothers and their Young Children's Nutrition: Lower Pra Rural Bank Credit with Education Program in Ghana, Freedom from Hunger Research Paper 4, Davis: University of California, www.ffhtechnical.org/resources/ research-and-evaluation/impact-studies/ Ghana\%20Nutrition\%2Olmpact\%20Study/Ghana\% 20Nutrition\%2OImpact\%20Study\%203-98-eng.pdf/ download (accessed 9 July 2008)

Morduch, J. (2006) 'Micro-insurance: The Next Revolution?', in A. Banerjee, R. Benabou and D. Mookherjee (eds), Understanding Poverty, Oxford: Oxford University Press: 337-56

Moser, C. (1998) 'The Asset Vulnerability Framework: Reassessing Urban Poverty Reduction Strategies', World Development 26.1: 1-19 
Norwegian Nobel Committee (2006) The Nobel Prize for 2006, press release 13 October, http://nobelprize.org/nobel_prizes/peace/laureates /2006/press.html (accessed 20 June 2008)

Pantoja, E. (2002) 'Microfinance and Disaster Risk Management: Experiences and Lessons Learned', Prevention Consortium Draft Final Report (July 2002), www.proventionconsortium.org/themes/ default/pdfs/microfin_DRM.pdf (accessed 9 July 2008)

Scoones, I. (1998) Sustainable Rural Livelihoods: A Framework for Analysis, IDS Working Paper 72, Brighton: IDS
Swain, R.B. and Floro, M. (2007) Effect of Microfinance on Vulnerability, Poverty and Risk in Low Income Households, Working Paper 31, Department of Economics, Uppsala University, Sweden, www.nek.uu.se/Pdf/wp2007_31.pdf (accessed 10 July 2008)

Swift, J. (1989) 'Why are Rural People Vulnerable to Famine?', IDS Bulletin 20.2: 8-15

Tompkins, E.L. and Adger, W.N. (2003) Building Resilience to Climate Change Through Adaptive Management of Natural Resources, Tyndall Working Paper 27, Norwich: Tyndall Centre 